\title{
Improvement in genetic characteristics and oil yield of selected soybean progenies from octuple crosses*
}

\author{
Osvaldo Toshiyuki Hamawaki ${ }^{1}$, Natal Antônio Vello² and Claudinei Antonio Didoné2
}

\begin{abstract}
The objective of the present study was to evaluate 44 soybean octuple crosses in the $\mathrm{F}_{4: 3[8]}$ and $\mathrm{F}_{5: 3[8]}$ generations in order to select progenies superior for seed oil yield (OY) and other important agronomic characteristics. Octuple crosses were hybridized in a chain mating system. In one group, crosses were carried out for three generations with the adapted x exotic parents until octuple crosses with $75 \%$ adapted genes and $25 \%$ exotic genes were obtained. In a second group, hybridization of adapted x adapted parents originated crosses with $100 \%$ adapted genes. During the growing season 1994/95, the progenies $\mathrm{F}_{4: 3[8]}$ were evaluated by using the augmented block design. The progenies $\mathrm{F}_{5: 3[8]}$ were evaluated during the growing season 1995/96 in three experiments using augmented block design without repetition. The octuple crosses gave origin to superior progenies for all the characters studied. In the C22 cross, OY values were $707 \mathrm{~kg} /$ ha. The estimates of heritability in relation to the crosses average resulted in the following mean, minimum and maximum values, respectively: number of days to maturity $(52.35 \%, 3.71 \%, 84.23 \%)$; agronomic value $(26.69 \%, 1.62 \%, 61.28 \%)$ and grain yield $(29.28 \%$, $1.52 \%, 61.06 \%)$. The observed genetic gains for grain yield in the early, intermediate and late $\mathrm{F}_{5: 3[8]}$ progenies were superior to the expected genetic gains and the observed genetic gains for OY were more expressive in the early and late $\mathrm{F}_{5:[8]}$ progenies. The genetic variability remaining in the selected progenies of some crosses suggests that further genetic gains for grain yield and OY might be possible with advanced selection cycles.
\end{abstract}

\section{INTRODUCTION}

The soybean [Glycine $\max (\mathrm{L}$.$) Merrill] is an oleagi-$ nous plant that has been cultivated for more than 5,000 years. Domestication of soybeans occurred between 1500 and 1027 BC in northeastern China (Hymowitz, 1970) and these legumes became a basic food of the Chinese people. There is a consensus among the majority of authors that the most probable primary center of genetic species diversity for Glycine max is located in the central-south region of China, with the secondary center in Manchuria.

A rapid expansion of soybean cultivation in Brazil occurred in the 1970's, when the country became the second largest soybean producer in the world, following the US (Embrapa, 1997). The production of soybeans in Brazil reached 30 million tons, produced on approximately 13 million hectares, in the growing season 1997/98 (Embrapa, 1997, 1998).

Soybeans contribute 20 to $25 \%$ of the total production of oil and edible fat, accounting for 30 to $35 \%$ of the world production of vegetable oil. The primary competitor to soybeans in the market is the growing production of palm oil (Smith and Huyser, 1987). The key to maintaining the competitiveness of Brazilian soybeans in the international market is the exploitation of the fact that Brazilian varieties contain more oil, primarily as a consequence of the tropical and subtropical conditions under which they are cultivated. The loss of market share by North American soybean producers has been attributed to the superior quality of soybeans originating from Brazil and Argentina. Japanese processors have shown that the grain imported from Brazil in 1992 has an average of $1.25 \%$ more oil and $1.16 \%$ fewer impurities (Hill et al., 1996).

After three cycles of recurrent selection, Ininda et al. (1996) suggested that selection of populations developed from top quality varieties continues to be the most efficient way to obtain varieties of high productivity.

In view of the genetic variation in the characteristics of oil observed among the Brazilian soybean varieties, the utilization of genetic variation appears to be a promising tool for improvement programs with the goal of increasing grain contents. The use of exotic germoplasm for the enhancement of the species in adapted populations has been used for the improvement of quantitative characteristic (Vello, 1992) and has detected a quantitative interference of the characteristic of oil (Farias Neto, 1995; LaínezMejia, 1996). In consideration of the potential gains in adaptation and production, this approach may guide recommendations for crosses among divergent genotypes.

Recurrent selection (Miranda, 1994) has resulted in increased oil content. The author suggests that the scheme of the divergent recurrent selection (with the utilization of genetic male sterility) is an efficient way to increase seed weight and to raise the concentration of oil in the soybean seeds of the composite IAC- 1 .

The estimates of heritability are in agreement with

*Part of thesis presented by O.T.H. to the Department of Genetics, ESALQ/USP, 1998, in partial fulfillment of the requirements for the Ph.D. degree. ${ }^{1}$ Instituto de Ciências Agrárias, Universidade Federal de Uberlândia, 38400-902 Uberlândia, MG, Brasil. Send correspondence to O.T.H. ${ }^{2}$ Departamento de Genética, ESALQ/USP, Caixa Postal 83, 13400-970 Piracicaba, SP, Brasil. 
those values obtained for most characteristics evaluated in improvement programs. However, for the characteristic of grain productivity (low heritability), the estimates show a greater discrepancy (Rose et al., 1992; Farias Neto, 1995; Santos et al., 1995; Laínez-Mejia, 1996). The heritability for the characteristic of percentage of oil is relatively high, ranging from 44 to 84\% (Laínez-Mejia, 1996; Pantalone et al., 1996). However, for the heritability of the oil yield (OY), the values are lower, ranging from 29 to $86 \%$ (Miranda et al., 1989; Farias Neto, 1995; Laínez-Mejia, 1996). Higher heritability values were found for the characteristic of maturity, which ranged from 61 to $93 \%$ (Santos et al., 1995; Laínez-Mejia, 1996). Lopes (1997) found more disparate values in soybean octuple crosses, with estimates ranging from 24.27 to $95.80 \%$. In agronomic values, the estimates ranged from 0 to $89.03 \%$ (Farias Neto, 1995; Gomes, 1995; Laínez-Mejia, 1996; Lopes, 1997; Azevedo Filho, 1997).

The reports of genetic gains in grain yield (GY) have reached values of $19 \%$ in the second selection cycle in relation to the first cycle, and were obtained by Karmakar and Bhatnagar (1996) in India, who reported an average gain of $22 \mathrm{~kg} / \mathrm{ha} /$ year. Maximizing genetic gain in GY through recurrent selection may be achieved by selecting a greater number of progenies resulting from two-parent crosses, followed by one generation of recombination instead of three generations of recombination (Uphoff et al., 1997).

Miranda et al. (1989) submitted the composite IAC1 , with genetic male sterility, to recurrent selection for an increase in the concentration of oil. They obtained an estimated genetic gain of $0.82 \%$ of oil per selection cycle in relation to the average of the population. They also concluded that the phenotypic selection at the level of the male sterile plant, as well as that based on average progeny of a male sterile plant, was sufficient to increase the concentration of oil. The composite IAC-1 has proved to be appropriate for recurrent selection with the aim of increasing the concentration of oil, since it has a great variability in relation to the percentage of total fatty acid. Rose $e t a l$. (1992) estimated the genetic gain in grain productivity through recurrent selection to be $128 \mathrm{~kg} / \mathrm{ha} /$ cycle.

The results reported in this study were obtained as part of the improvement programs for soybeans in the Department of Genetics of ESALQ/USP. The objectives of this project were to select superior genotypes for agronomic characteristics with emphasis on OY. This selection followed the evaluation at the level of field progenies $\mathrm{F}_{4: 3[8]}$ and $\mathrm{F}_{5: 3[8]}$ resulting from 45 octuple soybean crosses. In addition, we intended to obtain estimates of genetic parameters at the level of crosses and cycles relevant to the agronomic characteristics considered most important for the selection.

\section{MATERIAL AND METHODS}

The genotypes used in this project were progenies developed in the Soybean Improvement Program/Oil Yield, which is being developed in the Seção de Genética Aplicada a Espécies Autógomas, Departamento de Genética, Escola Superior de Agricultura 'Luis de Queiroz', University of São Paulo (ESALQ/USP).

All initial phases of the recurrent selection, including the three recombination cycles and the advances of the generations $\mathrm{F}_{1[8]}$ and $\mathrm{F}_{2[8]}$, were performed during the growing seasons from $1988 / 89$ to $1992 / 93$ by the staff of ESALQ/USP. The procedure used to obtain the quadruple and octuple two-parent crosses was that described by Vello (1992). This method was used to obtain 44 octuple crosses. In the autumn-winter (March to September) of 1994, the generation $\mathrm{F}_{3: 2[8]}$ was obtained. No field evaluation was made at this time since the main objective was the multiplication of the seed progenies. The generations $\mathrm{F}_{4: 3[8]}$ and $\mathrm{F}_{5: 3[8]}$ were obtained and evaluated during the growing seasons of 1994/ 95 and 1995/96, respectively.

The progenies $\mathrm{F}_{4: 3[8]}$ and $\mathrm{F}_{5: 3[8]}$ were obtained from 44 crosses involving 40 parents, which were divided into two groups of 20 genotypes, making two chained crosses. The designation of the octuple crosses differed from the one used for the simple crosses and was similar to the one adopted by Lopes (1997). The symbols $\mathrm{F}_{4: 3[8]}$ and $\mathrm{F}_{5: 4[8]}$ were adopted, with the symbol [8] coming with the identification of each generation, making its origin clear from the cross of eight parents. The first group of crosses was named mixed chain and included 10 exotic genotypes and 10 adapted genotypes, consisting of hybrid combinations showing $50 \%$ of the exotic genes. The second group of genotypes, called adaptedchained crosses, consisted of 20 adapted genotypes.

The initial phases of the recurrent selection process and the experiments of the $\mathrm{F}_{4: 3[8]}$ generation, whose progenies represent the present study material, were conducted in the experimental area of the ESALQ/USP headquarters. This location is situated in Piracicaba - SP, at $22^{\circ} 42^{\prime} 30^{\prime \prime}$ latitude south, $47^{\circ} 39^{\prime}$ '00' longitude west, $540 \mathrm{~m}$ above sea level, and the soil is of the 'terra-roxa estruturada' type (very similar to the American Argiustoll).

The experiments with progenies $\mathrm{F}_{5: 3[8]}$ were performed at the Anhembi Experimental Station, which also belongs to the Department of Genetics at ESALQ/USP, and is located $60 \mathrm{~km}$ away from the ESALQ headquarters. The soil is sandy and acidic with aluminum at toxic levels and low concentration of phosphorus. These soils are representative of those found in the Brazilian 'cerrado' (very similar to the American Savannah).

In 1994 and 1995, we evaluated 1,872 progenies of $\mathrm{F}_{4: 3[8]}$ in the experimental fields of ESALQ/USP. The sowing was performed on December 5, 1994. The treatments consisted of 1,872 progenies $\mathrm{F}_{4: 3[8]}$ and four checks (varieties: IAC-12, UFV-4, Bossier and IAC-Santa Maria-702). Sketching in augmented blocks was used [Federer blocks (Federer, 1956)]. The progenies were distributed in 82 groups, without repetition. Each lot was formed by a row of $5.0 \mathrm{~m} \times 0.5 \mathrm{~m}$. The four checks were included in all the groups, representing ordinary treatments. 
The experimental data were used for the selection of superior progenies and a different intensity of selection was applied to each cross. This selection was based upon the following characteristics, in order of importance: GY; agronomic value (AV) - overall appearance, evaluated the maturity through a visual scale ranging from 1 to 5 , in which 1 represented a plot with plants of no agronomic value, and 5 represented a plot having plants with excellent agronomic value, lodging, and cycle.

The progenies $\mathrm{F}_{5: 3[8]}$ obtained by selection from $\mathrm{F}_{4: 3[8]}$ and the four checks (IAC-12, UFV-4, Bossier and IAC-Santa Maria-702) were sowed on December 6, 1995 at the Anhembi Experimental Station. The plots consisted of two rows, each $5.0 \mathrm{~m}$ in length. Spaces inside the rows were $0.5 \mathrm{~m}$ and the spaces between the plots were $1.0 \mathrm{~m}$.

The selection used for the previous generation resulted in 836 progenies of $\mathrm{F}_{5: 3[8]}$, which were evaluated with the four checks (IAC-12, UFV-4, Bossier and IAC-Santa Maria-702). This was carried out in 35 groups, in six experiments. The number of progenies in each experiment varied, as it was defined according to the progenies of the previous generation. The procedures adopted for these experiments were the same as those described for the previous generation.

The evaluation of the progenies $\mathrm{F}_{4: 3[8]}, \mathrm{F}_{5: 3[8]}$ and the checks was based on the following characteristics. Number of days for maturity (NDM) was defined as the period of time between the day of the sowing and the day on which approximately $95 \%$ of the pods were mature. The $\mathrm{AV}$ reflects the global aspect of the plants with respect to a series of adaptable characteristics. These qualities consisted of the quantity of pods, vigor in terms of height and number of ramifications, health of the plants, viability to a mechanized harvest, resistance to premature thrashing of pods and leaf-like retention after reaching maturity. GY was evaluated based upon the yield in $\mathrm{kg} / \mathrm{ha}$, after a period of time (approximately 30 days) of storage of the grain for drying in the dark and at ambient temperature.

Concentration of oil in the grain, expressed as percentage (\%OL), was determined in a sample of about 18 whole grains per lot with inner humidity around $6 \%$ by nuclear magnetic resonance.

OY, or oil productivity, was obtained by multiplying the concentration of oil by the GY of oil by the grain productivity of each plot and is reported as $\mathrm{kg} / \mathrm{ha}$.

The data from the observations in the experimental lots were subjected to a separate analysis of variance for each characteristic. The agronomic values were previously transformed into $(x+0.5)^{1 / 2}$. The mathematical model adopted was as follows:

$$
y_{i j k}=u+b_{i}+c_{j}+g\left({ }_{j k}\right)+e_{i j o k}
$$

where $\mathrm{y}_{\mathrm{ijk}}$ is the observation (y) in the lot $\mathrm{ijk}(\mathrm{i}=1,2, \ldots, \mathrm{B}$ blocks or groups; $\mathrm{j}=1,2, \ldots, \mathrm{C}$ crosses, and $\mathrm{k}=1,2, \ldots, \mathrm{g}$ genotypes in the cross $j$ ). The average of the observation is given by $\mathrm{u}$, and $\mathrm{b}_{\mathrm{i}}$ is the aleatory effect of the ith block.

The fixed effect of the jth cross is given by $c_{j}$. The effect of the kth genotype inside the jth cross is expressed as $\mathrm{g}_{\mathrm{jk}}$. Finally, $\mathrm{e}_{\mathrm{ijk}}$ represents the experimental error in the referred plot, assumed to be independent and with a normal distribution of average zero and variance $\sigma^{2}$.

Statistical analyses were performed using the GLM procedure of SAS ${ }^{\circledR}$ (SAS Institute, 1987). The variance from the source "crosses + checks" was partitioned by determining the orthogonal contrasts for the effect of crosses (those that produced the progenies), the effect of checks, and the effect of crosses versus checks. The average variance due to the genotype inside crosses (G/ C) was partitioned for genotypes inside each cross which produced progenies to this generation $(\mathrm{G} / \mathrm{C} 1, \mathrm{G} / \mathrm{C} 2, \mathrm{G} /$ 45). Although the program started with 44 crosses, progenies of the cross number 37 did not produce any seeds. The analysis produced estimates of components of variance for genotypes inside the crosses and for the average crosses and genotypes inside the crosses. All estimates were adjusted for blocks, as well as for the associated pattern errors.

The analysis of variance for each of the six experiments conducted on the $\mathrm{F}_{5: 3[8]}$ generation followed the same model as that of the previous generation with the exception that in the current generation, the effects of the genotypes inside the crosses were assumed to be fixed as a result of rigorous selection. The number of crosses, which resulted in the progenies of each experiment, varied considerably from 40 crosses in experiments 1 and 3 to 23 crosses in 4 . The same was true for the number of genotypes inside the crosses.

The estimates of variance of genotypes and of heritability in terms of averages for characteristics inside the crosses were obtained for the $\mathrm{F}_{4: 3[8]}$ generation using least square means analysis of variance.

The heritability $\left(h^{2}\right)$ for each character was estimated by the formula:

$$
\mathrm{h}^{2}=\frac{\sigma_{\mathrm{p} / \mathrm{c}}^{2}}{\sigma_{\mathrm{p} / \mathrm{c}}^{2}+\sigma_{\mathrm{e}}^{2}} \times 100
$$

where $\sigma_{\mathrm{p} / \mathrm{c}}^{2}$ is the estimate of the component of variance for progenies inside the crosses which is given by:

$$
\begin{aligned}
& \sigma_{\mathrm{p} / \mathrm{c}}^{2}=\mathrm{QM}_{\mathrm{P} / \mathrm{C}}-\mathrm{QM}_{\text {Error; }} \\
& \sigma_{\mathrm{e}}^{2} \text { is the estimate of error and is given by: } \\
& \sigma_{\mathrm{e}}^{2}=\mathrm{QM}_{\mathrm{Error}}
\end{aligned}
$$

The genetic gains expected for each character and cross with respect to the progenies selected for $\mathrm{F}_{4: 3[8]}$ were estimated. This was done with the objective to identify those with a greater improvement potential. The charac- 
teristic GY was chosen as the basis of comparison of the estimated gains with the actual gains observed in the selection process.

The estimates of the genetic gains (Gs) were calculated from the formula $\mathrm{Gs}=\mathrm{ds} . \mathrm{h}^{2}$, where ds is the differential of selection, defined as ds $=\mathrm{Xs}-\mathrm{Xo}$, where Xs represents the crosses average in the generation $\mathrm{F}_{4: 3[8]}$ and includes only the selected progenies, and Xo is the general average of the cross in the same generation. The values of genetic gains are expressed as percentage calculated as $\mathrm{Gs}=(\mathrm{Gs} / \mathrm{Xo}) \times 100$. The observed genetic gain was obtained from the evaluation of the selected progenies in the generation $\mathrm{F}_{5: 3[8]}$. Genetic gains were calculated using adjusted averages in both generations for each cross and character of the progenies. It was necessary to carry out an adjustment of the averages found in the conjoint analysis, gathering all the progenies (early, intermediate and late) of one cross, also in the second generation. The adjustment was carried out by analysis of conjoint models using the SAS PROC GLM program.

Given that both generations were tested during different years, we adjusted the average population for the second year. The expression used to calculate the adjusted observed genetic gain $\left(\mathrm{G}_{\mathrm{o}}\right)$ was given by:

$$
\mathrm{G}_{\mathrm{o}}=\mathrm{X}_{\mathrm{M}}-\mathrm{X}_{\mathrm{o}} \text { (adjust.), }
$$

where $X_{M}$ is the average of the progenies of the improved population (generation $F_{5: 3[8]}$ ), and $X_{o}$ (adjust.) $=X_{o}+a$. In the latter formula, $\mathrm{a}$ is the average of the original population, with "a" representing the adjustment for the effect of year, given by the difference between the checks average (Xt) in both years and "a" is calculated using the formula

$$
\mathrm{a}=\mathrm{Xt}(\text { year 1) }-\mathrm{Xt}(\text { year 2) }
$$

Considering that the characteristic for concentration of oil was measured only in the best $\mathrm{F}_{4: 3[8]}$ progenies, an adaptation was made to find an approximation of the obtained gain in this character with the selection. The adjusted average for the character in the original population $\left(\mathrm{F}_{4: 3[8]}\right)$ was calculated as the product of the adjusted average of $\mathrm{GY}$ and the respective average concentration of oil (\%OL) of the progenies. For the adjustment of the effect of years the estimates of the average concentration of oil found by Laínez-Mejia $(1996)$ were used. These estimates were Bossier $=22.3 \%$; UFV $-4=22.5 \%$; Santa Maria $=21.3 \%$ and IAC- $12=22.3 \%$.

In a second step the averages of the $\mathrm{F}_{4: 3[8]}$ progenies (original population) were grouped regarding the progeny maturation cycle. In this way, it was possible to determine the observed gain with the selection for each character per cross and cycle. The expression to evaluate these gains was the same as that used before, including the adjustment made for the effect of "years".

\section{RESULTS AND DISCUSSION}

The results of the 44 octuple crosses are given in Tables I to V (identified by the numbers $\mathrm{C} 1$ to $\mathrm{C} 45$ ), with the respective genealogy in Table VI. The checks are coded as follows: 46, UFV-4; 47, Bossier; 48, IAC-Santa Maria 702, and 49, IAC-12.

Table I - Estimates of adjusted averages to grain yield (GY) and oil yield (OY) in $\mathrm{F}_{5: 3[8]}$ progenies grouped in only one cycle, and of contents and $\mathrm{OY}$ and $\mathrm{GY}$ in the selected $\mathrm{F}_{4: 3[8]}$ progenies obtained from chained crosses. Soybean, Piracicaba-SP, sowed on

\begin{tabular}{|c|c|c|c|c|c|c|c|c|}
\hline \multirow[t]{3}{*}{ Cross } & \multicolumn{4}{|c|}{$\mathrm{F}_{5: 3[8]}$} & \multicolumn{4}{|c|}{$\mathrm{F}_{4: 3[8]}$} \\
\hline & \multicolumn{2}{|r|}{ GY } & \multicolumn{2}{|c|}{ OY } & \multirow[t]{2}{*}{$\mathrm{N}$} & \multirow[t]{2}{*}{$\% \mathrm{OL}$} & OY & \multirow[t]{2}{*}{ GY } \\
\hline & $\mathrm{N}$ & $\mathrm{kg} / \mathrm{ha}$ & $\mathrm{N}$ & $\mathrm{kg} / \mathrm{ha}$ & & & $\mathrm{kg} / \mathrm{ha}$ & \\
\hline 1 & 22 & 2558 & 21 & 532.4 & 21 & 24.24 & 318.9 & 1316 \\
\hline 2 & 14 & 2586 & 13 & 610.8 & 13 & 23.44 & 290.2 & 1238 \\
\hline 3 & 24 & 2725 & 22 & 606.8 & 23 & 24.21 & 295.7 & 1221 \\
\hline 4 & 24 & 2446 & 24 & 520.9 & 23 & 23.83 & 298.0 & 1248 \\
\hline 5 & 19 & 2005 & 17 & 452.2 & 19 & 23.58 & 281.0 & 1192 \\
\hline 6 & 18 & 2285 & 4 & 569.5 & 20 & 23.21 & 272.5 & 1174 \\
\hline 7 & 23 & 2667 & 7 & 546.5 & 10 & 24.46 & 316.0 & 1292 \\
\hline 8 & 25 & 3042 & 11 & 669.2 & 17 & 24.49 & 404.0 & 1650 \\
\hline 9 & 24 & 2684 & 15 & 581.6 & 18 & 24.43 & 321.2 & 1315 \\
\hline 10 & 19 & 2529 & 14 & 510.4 & 14 & 23.71 & 292.3 & 1233 \\
\hline 11 & 27 & 2259 & 23 & 483.5 & 23 & 24.14 & 261.4 & 1083 \\
\hline 12 & 39 & 2601 & 17 & 486.3 & 17 & 23.76 & 290.6 & 1223 \\
\hline 13 & 33 & 3073 & 18 & 606.3 & 17 & 24.09 & 249.0 & 1034 \\
\hline 14 & 31 & 2905 & 22 & 624.0 & 20 & 22.77 & 251.0 & 1102 \\
\hline 15 & 20 & 2761 & 9 & 579.5 & 7 & 24.62 & 311.2 & 1264 \\
\hline 16 & 21 & 2796 & 16 & 558.9 & 16 & 24.80 & 324.9 & 1310 \\
\hline 17 & 33 & 2539 & 20 & 505.0 & 21 & 24.41 & 273.1 & 1119 \\
\hline 18 & 18 & 2616 & 11 & 530.1 & 10 & 24.54 & 323.2 & 1317 \\
\hline 19 & 28 & 2620 & 24 & 535.0 & 22 & 24.03 & 294.1 & 1224 \\
\hline 20 & 42 & 2718 & 30 & 481.6 & 25 & 23.64 & 328.1 & 1388 \\
\hline 21 & 25 & 1617 & 13 & 346.2 & 15 & 24.52 & 268.5 & 1095 \\
\hline 22 & 28 & 2869 & 13 & 707.0 & 11 & 23.60 & 290.3 & 1230 \\
\hline 23 & 33 & 2293 & 12 & 520.6 & 14 & 24.11 & 308.8 & 1281 \\
\hline 24 & 28 & 2516 & 16 & 513.6 & 14 & 24.13 & 325.5 & 1349 \\
\hline 25 & 35 & 2959 & 24 & 648.7 & 23 & 24.65 & 270.0 & 1094 \\
\hline 26 & 32 & 2404 & 19 & 457.0 & 21 & 24.55 & 320.0 & 1303 \\
\hline 27 & 34 & 2472 & 17 & 494.0 & 20 & 24.28 & 244.2 & 1006 \\
\hline 28 & 27 & 2469 & 16 & 425.8 & 19 & 24.07 & 258.0 & 1070 \\
\hline 29 & 36 & 2485 & 23 & 501.5 & 23 & 24.21 & 191.5 & 791 \\
\hline 30 & 28 & 2793 & 20 & 556.6 & 19 & 24.45 & 293.4 & 1200 \\
\hline 31 & 23 & 2902 & 19 & 603.0 & 20 & 24.14 & 301.5 & 1249 \\
\hline 32 & 28 & 2351 & 17 & 420.0 & 19 & 24.34 & 352.4 & 1448 \\
\hline 33 & 20 & 2468 & 8 & 542.0 & 8 & 22.70 & 275.6 & 1303 \\
\hline 34 & 26 & 2617 & 12 & 531.0 & 14 & 21.91 & 272.1 & 1242 \\
\hline 35 & 29 & 2243 & 13 & 388.5 & 16 & 23.73 & 299.2 & 1261 \\
\hline 36 & 31 & 2244 & 16 & 411.0 & 22 & 23.75 & 283.8 & 1195 \\
\hline 38 & 2 & 2652 & 2 & 584.0 & 2 & 20.52 & 161.5 & 787 \\
\hline 39 & 8 & 2679 & 2 & 577.0 & 2 & 22.50 & 231.0 & 1027 \\
\hline 40 & 12 & 3161 & 9 & 558.0 & 18 & 23.34 & 227.0 & 973 \\
\hline 41 & 18 & 2790 & 15 & 506.0 & 15 & 23.31 & 222.1 & 953 \\
\hline 42 & 18 & 2839 & 6 & 564.0 & 19 & 23.66 & 277.0 & 1171 \\
\hline 43 & 26 & 3022 & 9 & 563.0 & 24 & 23.31 & 277.9 & 1175 \\
\hline 44 & 26 & 2781 & 25 & 638.1 & 29 & 23.16 & 256.8 & 1109 \\
\hline 45 & 7 & 1690 & 7 & 358.0 & 4 & 24.41 & 275.8 & 1130 \\
\hline 46 & 6 & 2392 & 6 & 414.3 & 1 & 22.50 & 300.1 & - \\
\hline 47 & 6 & 2032 & 6 & 464.7 & 1 & 22.30 & 177.5 & - \\
\hline 48 & 4 & 2600 & 6 & 436.3 & 1 & 21.30 & 152.5 & - \\
\hline 49 & 3 & 2077 & 2 & 431.0 & 1 & 22.30 & 196.7 & - \\
\hline \multicolumn{2}{|c|}{$\begin{array}{l}\text { General } \\
\text { average }\end{array}$} & 2317 & & 524.0 & & 23.81 & 277.2 & 1191 \\
\hline
\end{tabular}
December 5, 1994 and December 6, 1996. 
Table II - Estimates of adjusted average $(\overline{\mathrm{x}})$ and pattern error of the average $[\mathrm{s}(\overline{\mathrm{x}})]$ found in early, intermediate and late $\mathrm{F}_{5: 3[8]}$ progenies from chained crosses. Soybean, Piracicaba-SP, sowed on December 6, 1995.

\begin{tabular}{|c|c|c|c|c|c|c|c|c|c|}
\hline \multirow[t]{2}{*}{ Cross } & \multicolumn{3}{|c|}{ Early } & \multicolumn{3}{|c|}{ Intermediate } & \multicolumn{3}{|c|}{ Late } \\
\hline & $\mathrm{N}$ & $\bar{x}$ & $\mathrm{~s}(\overline{\mathrm{x}})$ & $\mathrm{N}$ & $\overline{\mathrm{x}}$ & $s(\bar{x})$ & $\mathrm{N}$ & $\overline{\mathrm{x}}$ & $s(\bar{x})$ \\
\hline 1 & - & - & - & 2 & 487.09 & 109.46 & 2 & 530.48 & 90.29 \\
\hline 2 & - & - & - & 3 & 810.07 & 94.43 & 1 & 537.40 & 151.08 \\
\hline 3 & 3 & 713.27 & 145.96 & 2 & 665.14 & 120.37 & 1 & 615.50 & 151.08 \\
\hline 4 & 2 & 848.17 & 159.60 & 1 & 577.80 & 120.37 & - & - & - \\
\hline 5 & - & - & - & - & - & - & 1 & 842.10 & 151.08 \\
\hline 6 & - & - & - & - & - & - & 2 & 679.25 & 102.94 \\
\hline 8 & 1 & 781.51 & 194.88 & 4 & 784.67 & 83.46 & 2 & 631.95 & 102.94 \\
\hline 9 & - & - & - & 1 & 432.28 & 156.59 & 6 & 730.97 & 59.43 \\
\hline 10 & - & - & - & - & - & - & 1 & 514.83 & 114.20 \\
\hline 11 & 1 & 460.02 & 159.60 & - & - & - & - & - & - \\
\hline 12 & - & - & - & - & - & - & 1 & 566.73 & 114.20 \\
\hline 13 & 1 & 949.46 & 194.88 & 2 & 773.16 & 109.46 & 1 & 734.58 & 114.20 \\
\hline 14 & 2 & 796.83 & 159.60 & 3 & 697.37 & 73.14 & & - & - \\
\hline 15 & - & - & - & 2 & 534.19 & 114.68 & 2 & 673.28 & 102.94 \\
\hline 16 & 1 & 376.26 & 159.60 & 1 & 801.12 & 114.68 & 2 & 790.65 & 90.29 \\
\hline 18 & 1 & 501.54 & 194.88 & - & - & - & 1 & 357.88 & 151.08 \\
\hline 19 & 2 & 736.75 & 149.49 & - & - & - & 4 & 744.54 & 83.24 \\
\hline 20 & 3 & 545.06 & 145.96 & 5 & 671.78 & 82.05 & - & - & - \\
\hline 21 & & - & - & - & - & - & 1 & 802.58 & 114.20 \\
\hline 22 & 1 & 594.70 & 194.88 & 2 & 615.30 & 114.68 & 1 & 879.33 & 151.08 \\
\hline 23 & 1 & 738.77 & 221.57 & 1 & 750.75 & 114.68 & & - & - \\
\hline 24 & 3 & 629.50 & 180.05 & 1 & 751.14 & 152.26 & 1 & 918.23 & 151.08 \\
\hline 25 & 1 & 628.80 & 221.57 & 2 & 718.02 & 114.68 & 1 & 470.48 & 114.20 \\
\hline 26 & - & - & - & 1 & 755.49 & 152.26 & & - & - \\
\hline 28 & - & - & - & - & - & - & 2 & 663.05 & 102.94 \\
\hline 31 & - & - & - & 2 & 827.54 & 81.43 & 1 & 602.73 & 151.08 \\
\hline 32 & - & - & - & - & - & - & 3 & 562.24 & 87.23 \\
\hline 33 & - & - & - & - & - & - & 1 & 688.73 & 151.08 \\
\hline 34 & - & - & - & - & - & - & 1 & 878.08 & 114.20 \\
\hline 36 & - & - & - & 1 & 919.32 & 114.68 & 1 & 696.83 & 114.20 \\
\hline 40 & - & - & - & 1 & 804.89 & 114.68 & - & - & - \\
\hline 41 & 3 & 664.30 & 86.08 & 1 & 509.43 & 114.68 & - & - & - \\
\hline 43 & 5 & 594.00 & 106.04 & 2 & 729.07 & 114.68 & 1 & 588.78 & 114.20 \\
\hline 44 & 4 & 711.80 & 113.49 & 5 & 643.00 & 82.05 & 1 & 1181.23 & 151.08 \\
\hline 46 & 1 & 313.60 & 136.11 & 1 & 465.94 & 81.77 & 1 & 494.63 & 80.75 \\
\hline 47 & 1 & 476.11 & 194.88 & 1 & 376.63 & 105.57 & 1 & 378.77 & 80.75 \\
\hline 48 & 1 & 525.14 & 136.11 & 1 & 325.78 & 81.77 & 1 & 310.70 & 80.75 \\
\hline 49 & 1 & 514.98 & 136.11 & 1 & 584.18 & 81.77 & 1 & 412.30 & 80.75 \\
\hline Genera & Average & 629.83 & 161.49 & & 654.27 & 107.70 & & 649.29 & 108.57 \\
\hline
\end{tabular}

\section{Concentration and oil yield (oil productivity)}

The estimates referring to $\% \mathrm{OL}$ and $\mathrm{OY}$ in $94 / 95$ (Table I) were found only in the selected progenies of the $\mathrm{F}_{4: 3[8]}$ generation. The average OL was $23.81 \%$. Twenty-five crosses had larger OL values; C16 had 24.80, C15 had 24.62 , and $\mathrm{C} 25$ had $24.65 \%$. These values are high compared to those obtained in 1994-1995 by Lainez-Mejia (1996). This group obtained an average estimate for UFV4 of $22.50 \%$. UFV-4 is considered the most productive national variety for this characteristic.

The results of this study demonstrated a high potential for the selection of genetically superior alleles for OL. The crosses C15, C16 and C25 showed hybrid combinations in their genealogy that were identified by other authors as possessing traits of elevated concentration of oil:
IAC-9 x GO 79-1030, UFV-Araguaia x Sel. Bossier (Laínez-Mejia, 1996) and FT 81-2129 x Cobb, Sel. Paraná x Kirby (Farias Neto, 1995).

The values for OY obviously reflect those of GY, since they were determined as the product of GY and \%OL, with variability among the crosses as a reflection of the variability in GY. In the progenies of the $\mathrm{F}_{4: 3[8]}$ generation (Table I) it can be seen that 22 crosses had values higher (although they were not subjected to statistical analysis) than the general average of $303.1 \mathrm{~kg} / \mathrm{ha}$, with C38 $(158.8 \mathrm{~kg} / \mathrm{ha})$ being the least productive, and the crosses C5 $(396.8 \mathrm{~kg} / \mathrm{ha}), \mathrm{C} 8$ $(368.3 \mathrm{~kg} / \mathrm{ha})$, and C32 (353.3 kg/ha) having higher averages reflecting the respective $\mathrm{GY}$ of the selected progenies.

According to Montaño-Velasco (1994) the characters $\mathrm{OY}$ and $\mathrm{GY}$ show a high and positive correlation $(\mathrm{r}=$ 0.99), whereas GY and \%OL show a positive association, 
Table III - Estimates of genetic variant $\left(\sigma_{\mathrm{g} / \mathrm{c}}^{2}\right)$ inside the crosses and heritability $\left(\mathrm{h}^{2}\right)$ to the number of days for maturity (NDM), agronomic value $(\mathrm{AV})$ and grain yield $(\mathrm{GY})$ in $\mathrm{F}_{4: 3[8]}$ progenies obtained in the chained crosses. Soybean, Piracicaba-SP, sowing on December 5, 1994.

\begin{tabular}{|c|c|c|c|c|c|c|}
\hline \multirow[t]{2}{*}{ Cross } & \multicolumn{3}{|c|}{$\sigma_{g / c}^{2}$} & \multicolumn{3}{|c|}{$h^{2}$} \\
\hline & NDM & $\mathrm{AV}$ & GY & NDM & $\mathrm{AV}$ & GY \\
\hline 1 & $167.60 * *$ & $4648 * *$ & $79214 * *$ & 71.56 & 44.72 & 38.22 \\
\hline 2 & -15.03 & 0 & 35077 & 0.00 & 0.00 & 21.57 \\
\hline 3 & 11.24 & 16 & $107679 * *$ & 14.44 & 0.00 & 45.78 \\
\hline 4 & $299.45 * *$ & 1819 & 36785 & 81.79 & 24.05 & 22.39 \\
\hline 5 & $243.85 * *$ & -1540 & $68870^{* *}$ & 78.56 & 0.00 & 35.07 \\
\hline 6 & $200.65 * *$ & -723 & $200315^{* * *}$ & 75.06 & 0.00 & 61.06 \\
\hline 7 & $89.14 * *$ & 2182 & 46645 & 57.25 & 27.52 & 26.78 \\
\hline 8 & 18.55 & -1544 & $137644 * *$ & 21.77 & 0.00 & 51.91 \\
\hline 9 & -19.26 & -1892 & $50303^{*}$ & 0.00 & 0.00 & 28.29 \\
\hline 10 & 12.53 & 1349 & -5222 & 15.84 & 19.01 & 0.00 \\
\hline 11 & 2.57 & $4616 * *$ & -36103 & 3.71 & 44.55 & 0.00 \\
\hline 12 & $163.63 * *$ & 1067 & 94498 & 71.08 & 15.66 & 42.56 \\
\hline 13 & $143.11 * *$ & -497 & -45429 & 68.24 & 0.00 & 0.00 \\
\hline 14 & $26.80 * *$ & -3423 & 27895 & 28.69 & 0.00 & 17.95 \\
\hline 15 & $90.77 * *$ & -87 & $113292^{* * *}$ & 57.66 & 0.00 & 47.04 \\
\hline 16 & $36.98 * *$ & -2037 & $86403 * *$ & 35.69 & 0.00 & 40.39 \\
\hline 17 & $30.58 *$ & 307 & $99357 * *$ & 31.46 & 5.07 & 43.79 \\
\hline 18 & -33.90 & 1484 & $55966^{*}$ & 0.00 & 20.53 & 30.50 \\
\hline 19 & $56.87 * *$ & -1522 & 44460 & 46.04 & 0.00 & 25.85 \\
\hline 20 & $51.02 * *$ & $2237 *$ & $86005^{* * *}$ & 43.38 & 28.02 & 40.28 \\
\hline 21 & $241.97 * *$ & $3511 * *$ & 1972 & 78.40 & 37.93 & 1.52 \\
\hline 22 & $355.73 * *$ & $4853 * *$ & $87626^{* * *}$ & 84.23 & 45.79 & 40.73 \\
\hline 23 & 154.66 & 1131 & $102413^{* * *}$ & 69.88 & 16.45 & 44.54 \\
\hline 24 & $104.36^{* *}$ & -99 & $62245^{*}$ & 61.02 & 0.00 & 32.80 \\
\hline 25 & $57.65^{* *}$ & 1930 & 2787 & 46.37 & 25.14 & 2.13 \\
\hline 26 & $63.57 * *$ & $9092 * *$ & 27777 & 48.82 & 61.28 & 17.88 \\
\hline 27 & -8.34 & 1962 & 20904 & 0.00 & 25.46 & 14.08 \\
\hline 28 & $54.93 * *$ & $2966^{*}$ & -8614 & 45.20 & 34.05 & 0.00 \\
\hline 29 & $61.47 * *$ & 626 & -35604 & 47.98 & 9.82 & 0.00 \\
\hline 30 & $78.65 * *$ & -610 & 3224 & 54.12 & 0.00 & 2.46 \\
\hline 31 & $50.93 * *$ & 242 & $48723^{*}$ & 43.34 & 4.04 & 27.64 \\
\hline 32 & $54.00 * *$ & 543 & $60485^{*}$ & 44.77 & 8.63 & 32.17 \\
\hline 33 & $70.39 * *$ & -2559 & -35134 & 51.37 & 0.00 & 0.00 \\
\hline 34 & $161.60 * *$ & $5883 * *$ & 19650 & 70.81 & 50.59 & 13.35 \\
\hline 35 & 23.76 & -1963 & -25112 & 26.28 & 0.00 & 0.00 \\
\hline 36 & $256.80 * *$ & 1839 & 18368 & 79.40 & 24.25 & 12.59 \\
\hline 38 & -56.13 & 2573 & -114865 & 0.00 & 30.93 & 0.00 \\
\hline 39 & 58.34 & 1471 & 6759 & 46.70 & 20.38 & 5.03 \\
\hline 40 & $141.44 * *$ & -102 & 33105 & 68.00 & 0.00 & 20.61 \\
\hline 41 & $67.18 * *$ & -1344 & -7281 & 50.20 & 0.00 & 0.00 \\
\hline 42 & $30.55^{*}$ & -1564 & -42919 & 31.43 & 0.00 & 0.00 \\
\hline 43 & $84.78 * *$ & $4150^{* * *}$ & $85478^{* * *}$ & 55.99 & 41.94 & 40.13 \\
\hline 44 & $322.30 * *$ & 95 & $82475^{* * *}$ & 82.87 & 1.62 & 39.27 \\
\hline 45 & -38.31 & -1156 & -42383 & 0.00 & 0.00 & 0.00 \\
\hline
\end{tabular}

*,**Significant at $5 \%$ and $1 \%$ probability, respectively, by $\mathrm{F}$ test.

but one of low magnitude $(r=0.094)$, with some increase in the concentration of oil occurring in the most productive varieties.

The checks had a general average of $458 \mathrm{~kg} / \mathrm{ha}$ for the OY character, with UFV-4 and IAC- 12 showing higher values, a behavior that also reflects the observed variation in GY (Table II). The progenies $\mathrm{F}_{5: 3[8]}$ showed a general average of $488 \mathrm{~kg} / \mathrm{ha}$, with high values of OY for crosses such as $\mathrm{C} 44$ with $1181, \mathrm{C} 24$ with 918.2 , C34 with
878.08 , and C5 with $842.1 \mathrm{~kg} / \mathrm{ha}$ (late subpopulations); C36 with 919, C37 with 827.54 , and C2 with $810.07 \mathrm{~kg} /$ ha (subpopulations of the intermediate cycle), and C13 with 949.46 and C4 with $848.17 \mathrm{~kg} / \mathrm{ha}$ (early subpopulations). These values were higher than those observed for the UFV-4 variety, which is considered the superior one among national varieties in its oil concentration with an OY value of $494.63 \mathrm{~kg} / \mathrm{ha}$.

The low variability in \%OL and the dependence of $\mathrm{OY}$ in relation to the variability in GY (Farias Neto, 1995 and Laínez-Mejia, 1996) were confirmed by our results. Among the subpopulations of this generation, the same crosses in GY gave similar results for OY. For example, the crosses C24 with $918 \mathrm{~kg} / \mathrm{ha}$ and C44 with $1181 \mathrm{~kg} / \mathrm{ha}$ were the most productive for $\mathrm{OY}$ among all the studied progenies, as was seen for GY. Both of these crosses belonged to the late subpopulation with repetition. By comparison, the outstanding example of high OY averages were those described by Farias Neto (1995). These included the combinations SOC 81-216 x Andrews Púrpura, Andrews Púrpura x FT 81-2.706 and GO 81-11.094, which are present in the genealogy of the cross $\mathrm{C} 19$, and GO 81-11.094 x BR-11 which is present in the crosses $\mathrm{C} 19$ and C44 (Table VI).

\section{Genotypical variances and heritability}

The estimates of the average genetic variance from NDM (Table III) was 90.21 days $^{2}$, which ranged from -33.90 days $^{2}$ for the cross $\mathrm{C} 18$ to 355.73 days $^{2}$ for the cross C22, followed by $\mathrm{C} 44$ with 322.73 days $^{2}$. For the AV characteristic, the cross C26 stood out with 5883 and the smallest estimate of 16 was detected in C3. For the GY characteristic, C6 stood out with $200315(\mathrm{~kg} / \mathrm{ha})^{2}$ and C8 with 137644 $(\mathrm{kg} / \mathrm{ha})^{2}$. C21 had the smallest value for GY with $1972(\mathrm{~kg} /$ ha) ${ }^{2}$. The crosses C44 and C22 had significantly elevated estimates compared to the genetic variance terms of NDM. $\mathrm{C} 22$ had significant values for VA while both $\mathrm{C} 22$ and C44 had high values for GY. These results suggest a probable superiority in efficiency in the progeny selection inside the crosses with higher values of variance, as suggested by Gomes (1995).

Table III shows the results of the estimates of the coefficient of heritability based on the performance of the progenies $\mathrm{F}_{4: 3[8]}$ for the characteristics NDM, AV and $\mathrm{GY}$ in each cross. The values found for NDM were relatively low, ranging from zero (six crosses) to $82.87 \%$, with an average of $45.21 \%$. This value is below those reported by other authors (Laínez-Mejia, 1996; Santos et al., 1995). The results were similar to the values found in octuple crosses by Lopes (1997), in which smaller heritabilities were considered low in relation to those reported by other authors. These findings reflect the different influences among the multiple crosses, with a large magnitude of variability among the parents. For NDM, the heritabilities with values of zero resulted from negative variance, arising as a consequence of the small sample size 
Table IV - Expected genetic gain (Gs) and observed gains (Go), in the selection among soybean $\mathrm{F}_{4: 3[8]}$ progenies to the character grain yield (GY) and Go to oil yield (OY). Soybean, Piracicaba-SP, sowing on December 5, 1994.

\begin{tabular}{|c|c|c|c|c|c|c|}
\hline \multirow[t]{3}{*}{ Cross } & \multicolumn{4}{|c|}{ GY } & \multirow{2}{*}{\multicolumn{2}{|c|}{$\begin{array}{l}\text { OY } \\
\text { Go }\end{array}$}} \\
\hline & \multicolumn{2}{|c|}{ Gs } & \multicolumn{2}{|c|}{ Go } & & \\
\hline & $\mathrm{kg} / \mathrm{ha}$ & $\%$ & $\mathrm{~kg} / \mathrm{ha}$ & $\%$ & $\mathrm{~kg} / \mathrm{ha}$ & $\%$ \\
\hline 1 & 103.46 & 10.06 & 256 & 24.90 & 0.00 & 0.00 \\
\hline 2 & 71.39 & 8.75 & 501 & 61.77 & 90.80 & 31.20 \\
\hline 3 & 92.47 & 9.02 & 432 & 42.39 & 81.30 & 27.50 \\
\hline 4 & 40.97 & 3.77 & 87 & 8.02 & 0.00 & 0.00 \\
\hline 5 & 230.4 & 22.41 & 0 & 0.00 & 0.00 & 0.00 \\
\hline 6 & 180.12 & 18.16 & 20 & 2.02 & 0.00 & 0.00 \\
\hline 7 & 105.51 & 10.91 & 422 & 43.46 & 0.00 & 0.00 \\
\hline 8 & 132.88 & 10.83 & 541 & 44.09 & 35.40 & 8.76 \\
\hline 9 & 50.92 & 4.31 & 228 & 19.28 & 30.60 & 9.52 \\
\hline 10 & 0 & 0 & 161 & 14.71 & 0.00 & 0.00 \\
\hline 11 & 0 & 0 & 0 & 0.00 & 0.00 & 0.00 \\
\hline 12 & 123 & 12.02 & 304 & 29.71 & 0.00 & 0.00 \\
\hline 13 & 0 & 0 & 847 & 88.97 & 127.50 & 51.20 \\
\hline 14 & 16.33 & 1.6 & 635 & 63.75 & 143.20 & 57.05 \\
\hline 15 & 145.82 & 15.02 & 515 & 52.98 & 38.50 & 12.37 \\
\hline 16 & 105.01 & 10 & 472 & 44.95 & 4.20 & 1.29 \\
\hline 17 & 61.3 & 5.19 & 90 & 7.65 & 2.10 & 2.12 \\
\hline 18 & 96.38 & 8.85 & 258 & 23.80 & 0.00 & 0.00 \\
\hline 19 & 16.28 & 12.52 & 69 & 5.40 & 11.10 & 3.77 \\
\hline 20 & 99.49 & 8.25 & 244 & 20.33 & 0.00 & 0.00 \\
\hline 21 & 0 & 0 & 0 & 0.00 & 0.00 & 0.00 \\
\hline 22 & 107.52 & 10.38 & 555 & 53.96 & 186.90 & 64.38 \\
\hline 23 & 143.86 & 14.38 & 19 & 1.90 & 0.00 & 0.00 \\
\hline 24 & 64.28 & 5.43 & 65 & 5.52 & 0.00 & 0.00 \\
\hline 25 & 0 & 0 & 531 & 46.01 & 148.90 & 55.14 \\
\hline 26 & 43.62 & 3.72 & 0 & 0.00 & 0.00 & 0.00 \\
\hline 27 & 30.27 & 2.84 & 145 & 13.77 & 20.00 & 8.19 \\
\hline 28 & 0 & 0 & 307 & 34.57 & 0.00 & 0.00 \\
\hline 29 & 0 & 0 & 252 & 26.27 & 80.20 & 41.87 \\
\hline 30 & 51.9 & 5.08 & 497 & 48.63 & 33.40 & 11.38 \\
\hline 31 & 56.66 & 4.78 & 438 & 36.80 & 71.70 & 23.78 \\
\hline 32 & 83.96 & 7.05 & 0 & 0.00 & 0.00 & 0.00 \\
\hline 33 & 0 & 0 & 215 & 21.96 & 36.60 & 13.28 \\
\hline 34 & 14.95 & 1.26 & 157 & 13.23 & 29.10 & 10.69 \\
\hline 35 & 0 & 0 & 0 & 0.00 & 0.00 & 0.00 \\
\hline 36 & 15.37 & 1.54 & 0 & 0.00 & 0.00 & 0.00 \\
\hline 38 & 0 & 0 & 685 & 98.84 & 192.70 & 119.31 \\
\hline 39 & 26.7 & 3.45 & 624 & 79.89 & 116.20 & 50.30 \\
\hline 40 & 48.84 & 5.52 & 1000 & 112.73 & 101.20 & 44.58 \\
\hline 41 & 0 & 0 & 606 & 66.59 & 54.10 & 24.35 \\
\hline 42 & 0 & 0 & 317 & 25.40 & 57.20 & 20.64 \\
\hline 43 & 60.19 & 5.43 & 645 & 58.47 & 55.30 & 19.89 \\
\hline 44 & 54.58 & 5.09 & 428 & 39.66 & 151.50 & 54.93 \\
\hline 45 & 0 & 0 & 0 & 0.00 & 0.00 & 0.00 \\
\hline
\end{tabular}

in the crosses, some of which also showed low potential variability. The negative values of the estimates of genetic variance can be explained by the small number of plants in some crosses or estimates close to zero. In relation to the performance of the progenies regarding NDM, in particular, crosses C44, C4, C22, C36, C5, C6, C21, C34 and $\mathrm{C} 11$ had estimates higher than $70 \%$.

The heritabilities for AV had low estimates, which were in the range of zero to $61.28 \%$, with an average of
$15.17 \%$, and results showed a significant variation of values (Table III). Probably, this is due to the subjective evaluation of this characteristic due to variation in the interpretation of each researcher, with visual reading subjected to variation, and also because AV depends on various characters, thus increasing its complexity. Among the crosses, 19 had values above the average, with only C26 and C34 having estimates larger than 50\%. The magnitudes of the coefficients of heritabilities were lower than those observed by other authors, who described similar situations, particularly regarding the inconsistency of the estimates (Laínez-Mejia, 1996; Azevedo Filho, 1997).

The estimates of heritability for GY (Table III) had an average of $21.96 \%$ with 22 crosses showing higher values. In particular, crosses C6, C8, C15 and C3 had h2 values of $>45 \%$ and an additional seven crosses had values above $40 \%$, with minimum and maximum values of zero and $61.06 \%$. Rose et al. (1992), who also used multiple crosses, obtained results in agreement with our study. Our estimates are lower than those found by Lopes (1997) using octuple crosses, as well as those obtained by Alliprandini (1996) with quadruple crosses. Low heritability values for GY have also been described by several authors (Rose $e t$ al. 1992; Santos et al., 1995; Farias Neto, 1995; LaínezMejia, 1996) suggesting a consensus by these investigators that the cause is the influence of the environment on this characteristic, making it difficult to succeed in the selection applied in the first segregating generations.

\section{Genetic gains}

Tables IV and V show estimates of the expected and observed genetic gains resulting from the selection of progenies $\mathrm{F}_{4: 3[8]}$. The expected gains with the selection for $\mathrm{GY}$ in the progenies $\mathrm{F}_{4: 3[8]}$ ranged from zero (12 crosses) to $22.41 \%$ (C5). C1, C7, C8, C15, C16 and C22 showed gains ranging from 24.90 to $53.96 \%$, although the other crosses also had a very promising performance. Eight crosses had gains greater than $50 \%$. Particularly large genetic gains were seen, such as those of $\mathrm{C} 14$ with 88.97, C38 with 98.84 and C40 with $112.73 \%$ (Table IV). The observed gains (Table V) ranged from zero to $114 \%$ (C39), and eight crosses had estimates greater than $40 \%$. Cross 15 had an observed gain of $91.30 \%$, confirming the high expected gain.

The values of expected gains (Go) for GY (Table V) ranged from 0 to $207 \%$. Six crosses had estimates over $100 \%$, and 15 showed values for the expected gain greater than $30 \%$, with the estimates ranging from zero to $207 \%$ (C40). Notable crosses were C6 with an expected genetic gain of 191.2, C16 with 147.9, C12 with 112.7, C13 with 104.3 and $\mathrm{C} 14$ with $96.0 \%$ (Table V). C6 had an excellent overall performance with the greatest value in Gs (Table IV) and the second best in Go (Table V). Other crosses such as $\mathrm{C} 12$ and $\mathrm{C} 23$ presented superior results in terms of Gs and Go.

The observed gains (Go) in the three subpopulations 
Table $\mathbf{V}$ - Observed gains (Go), in the selection among early, intermediate and late $\mathrm{F}_{4: 3[8]}$ progenies to the characters grain productivity (GY) and oil yield (OY). Soybean, Piracicaba-SP, sowing on December 5, 1994 and December 6, 1995.

\begin{tabular}{|c|c|c|c|c|c|c|c|c|c|c|c|c|}
\hline \multirow[t]{4}{*}{ Cross } & \multicolumn{12}{|c|}{ Go } \\
\hline & \multicolumn{4}{|c|}{ Early } & \multicolumn{4}{|c|}{ Intermediate } & \multicolumn{4}{|c|}{ Late } \\
\hline & \multicolumn{2}{|c|}{ GY } & \multicolumn{2}{|c|}{ OY } & \multicolumn{2}{|c|}{ GY } & \multicolumn{2}{|c|}{ OY } & \multicolumn{2}{|c|}{ GY } & \multicolumn{2}{|c|}{ OY } \\
\hline & $\mathrm{kg} / \mathrm{ha}$ & $\%$ & $\mathrm{~kg} / \mathrm{ha}$ & $\%$ & $\mathrm{~kg} / \mathrm{ha}$ & $\%$ & $\mathrm{~kg} / \mathrm{ha}$ & $\%$ & $\mathrm{~kg} / \mathrm{ha}$ & $\%$ & $\mathrm{~kg} / \mathrm{ha}$ & $\%$ \\
\hline 1 & 217 & 23.50 & 13.73 & 4.72 & 368 & 36.50 & 9.55 & 3.00 & 225 & 20.30 & 0.0 & 0.00 \\
\hline 2 & 722 & 115.00 & 154.13 & 86.50 & 0 & 0.00 & 0.00 & 0.00 & 506 & 39.80 & 67.4 & 19.29 \\
\hline 3 & 728 & 83.70 & 192.72 & 76.94 & 131 & 10.20 & 0.00 & 0.00 & 273 & 16.90 & 0.0 & 0.00 \\
\hline 4 & 165 & 15.30 & 100.53 & 39.01 & 0 & 0.00 & 0.00 & 0.00 & 464 & 44.60 & 77.3 & 27.55 \\
\hline 5 & 0 & 0.00 & 0.00 & 0.00 & 0 & 0.00 & 0.00 & 0.00 & 105 & 10.00 & 0.0 & 0.00 \\
\hline 6 & 0 & 0.00 & 0.00 & 0.00 & 1409 & 191.20 & 263.30 & 99.68 & 421 & 38.40 & 160.9 & 51.89 \\
\hline 7 & 11 & 1.12 & 0.00 & 0.00 & 921 & 101.30 & 93.70 & 29.37 & 284 & 26.40 & - & - \\
\hline 8 & 0 & 0.00 & - & - & 452 & 39.30 & 354.89 & 111.30 & 186 & 14.50 & 7.5 & 1.80 \\
\hline 9 & 0 & 0.00 & - & - & 0 & 0.00 & 0.00 & 0.00 & 773 & 63.90 & 107.3 & 30.52 \\
\hline 10 & 407 & 51.80 & 75.80 & 27.32 & 135 & 11.30 & 0.00 & 0.00 & 230 & 22.70 & 22.8 & 10.46 \\
\hline 11 & 0 & 0.00 & 0.00 & 0.00 & 145 & 13.30 & 0.00 & 0.00 & 1529 & 212.60 & - & - \\
\hline 12 & 0 & 0.00 & 0.00 & 0.00 & 1092 & 112.70 & 209.60 & 88.71 & 218 & 16.36 & 0.0 & 0.00 \\
\hline 13 & 108 & 12.90 & 61.05 & 24.69 & 1122 & 104.30 & 235.58 & 82.73 & 1198 & 114.30 & - & - \\
\hline 14 & 145 & 17.60 & 77.05 & 34.98 & 951 & 96.00 & 174.84 & 70.07 & 897 & 82.70 & 232.6 & 85.78 \\
\hline 15 & 571 & 91.30 & - & - & 319 & 29.10 & 28.97 & 9.99 & 897 & 94.60 & 118.8 & 42.27 \\
\hline 16 & 0 & 0.00 & 0.00 & 0.00 & 1470 & 147.90 & 0.00 & 0.00 & 757 & 71.00 & 53.1 & 15.56 \\
\hline 17 & 0 & 0.00 & 0.00 & 0.00 & 94 & 9.28 & 37.31 & 13.46 & 286 & 18.50 & 58.9 & 17.54 \\
\hline 18 & 0 & 0.00 & - & - & 596 & 56.30 & 0.00 & 0.00 & 263 & 24.00 & 0.0 & 0.00 \\
\hline 19 & 0 & 0.00 & 0.00 & 0.00 & 99 & 8.80 & 0.00 & 0.00 & 729 & 50.50 & 65.9 & 16.55 \\
\hline 20 & 0 & 0.00 & 0.00 & 0.00 & 0 & 0.00 & 0.00 & 0.00 & 1451 & 142.10 & 234.7 & 85.62 \\
\hline 21 & 0 & 0.00 & 0.00 & 0.00 & 0 & 0.00 & 0.00 & 0.00 & 887 & 70.60 & 94.1 & 25.23 \\
\hline 22 & 90 & 10.50 & 95.52 & 44.47 & 0 & 0.00 & 0.00 & 0.00 & 2075 & 196.70 & 372.1 & 125.41 \\
\hline 23 & 0 & 0.00 & 189.08 & 79.37 & 784 & 78.50 & 113.85 & 36.32 & 0 & 0.00 & 0.0 & 0.00 \\
\hline 24 & 839 & 78.80 & 153.19 & 48.00 & 0 & 0.00 & 166.96 & 54.68 & 91 & 7.52 & 0.0 & 0.00 \\
\hline 25 & 0 & 0.00 & 0.00 & 0.00 & 1001 & 82.30 & 0.00 & 0.00 & 862 & 65.70 & 87.4 & 22.72 \\
\hline 26 & 0 & 0.00 & 0.00 & 0.00 & 152 & 13.10 & 0.00 & 0.00 & 684 & 54.40 & 0.0 & 0.00 \\
\hline 27 & 0 & 0.00 & 0.00 & 0.00 & 230 & 19.70 & 0.00 & 0.00 & 720 & 52.40 & 56.7 & 14.45 \\
\hline 28 & 0 & 0.00 & 0.00 & 0.00 & 830 & 71.10 & 0.00 & 0.00 & 320 & 28.60 & 34.9 & 11.60 \\
\hline 29 & 0 & 0.00 & 19.01 & 7.05 & 533 & 52.30 & 4.71 & 1.66 & 245 & 26.30 & 0.0 & 0.00 \\
\hline 30 & 0 & 0.00 & 8.53 & 3.33 & 812 & 77.30 & 0.00 & 0.00 & 689 & 57.60 & 155.6 & 83.19 \\
\hline 31 & 0 & 0.00 & 0.00 & - & 1044 & 85.70 & 0.00 & 0.00 & 940 & 79.70 & 106.9 & 31.39 \\
\hline 32 & 0 & 0.00 & 0.00 & 0.00 & 0 & 0.00 & 0.00 & 0.00 & 810 & 70.70 & 0.0 & 0.00 \\
\hline 33 & 0 & 0.00 & - & - & 334 & 32.20 & - & - & 518 & 53.00 & 35.1 & 12.17 \\
\hline 34 & 90 & 6.65 & 69.79 & 21.30 & 0 & 0.00 & 139.56 & 54.14 & 985 & 83.10 & 232.1 & 82.39 \\
\hline 35 & 0 & 0.00 & 0.00 & 0.00 & 0 & 0.00 & 0.00 & 0.00 & 767 & 70.00 & - & - \\
\hline 36 & 0 & 0.00 & 0.00 & 0.00 & 0 & 0.00 & 0.00 & 0.00 & 746 & 68.80 & 185.3 & 61.67 \\
\hline 38 & 529 & 76.30 & 236.53 & 142.67 & 0 & 0.00 & - & - & 0 & 0.00 & - & - \\
\hline 39 & 975 & 144.00 & 182.98 & 63.46 & 377 & 48.20 & 86.09 & 27.49 & 209 & 17.50 & - & - \\
\hline 39 & 975 & 144.00 & 182.98 & 63.46 & 377 & 48.20 & 86.09 & 27.49 & 209 & 17.50 & - & - \\
\hline 40 & 370 & 45.70 & 96.43 & 41.33 & 1745 & 207.00 & 120.00 & 34.15 & 836 & 79.30 & - & - \\
\hline 41 & 47 & 5.32 & 42.31 & 46.99 & 500 & 50.30 & 11.33 & 3.55 & 1277 & 151.50 & - & - \\
\hline 42 & 0 & 0.00 & 0.00 & 0.00 & 263 & 20.20 & - & - & 970 & 73.20 & - & - \\
\hline 43 & 0 & 0.00 & 80.27 & 31.22 & 521 & 43.80 & 37.84 & 12.63 & 1356 & 113.70 & - & - \\
\hline 44 & 332 & 28.80 & 117.68 & 39.14 & 817 & 75.00 & 152.45 & 57.34 & 0 & 0.00 & 0.0 & 0.00 \\
\hline 45 & 0 & 0.00 & 0.00 & 0.00 & 0 & 0.00 & 0.00 & 0.00 & 0 & 0.00 & 60.2 & 19.38 \\
\hline
\end{tabular}

of the progenies $\mathrm{F}_{5: 3[8]}$ were generally higher than their expected gains. Observed gains were also better than the 1.8 to $19 \%$ reported previously (Toledo et al., 1990; Karmaker and Bhatnagar, 1996).

The subpopulation of the intermediate cycle had crosses with superior performances with regard to both the expected and observed gains. This behavior differed from that of the late progenies, which did not have any crosses which resulted in higher estimates of Gs and Go. These results are consistent with the observations of LaínezMejia (1996).

These results indicate that it is possible to increase the productivity of grains through the selection of superior progenies in the $\mathrm{F}_{4: 3[8]}$ generation. This assertion is supported by the results of the seven crosses with superior performances for Gs and Go, as well as those of the 
Table VI - Composition of the 44 octuple soybean crosses.

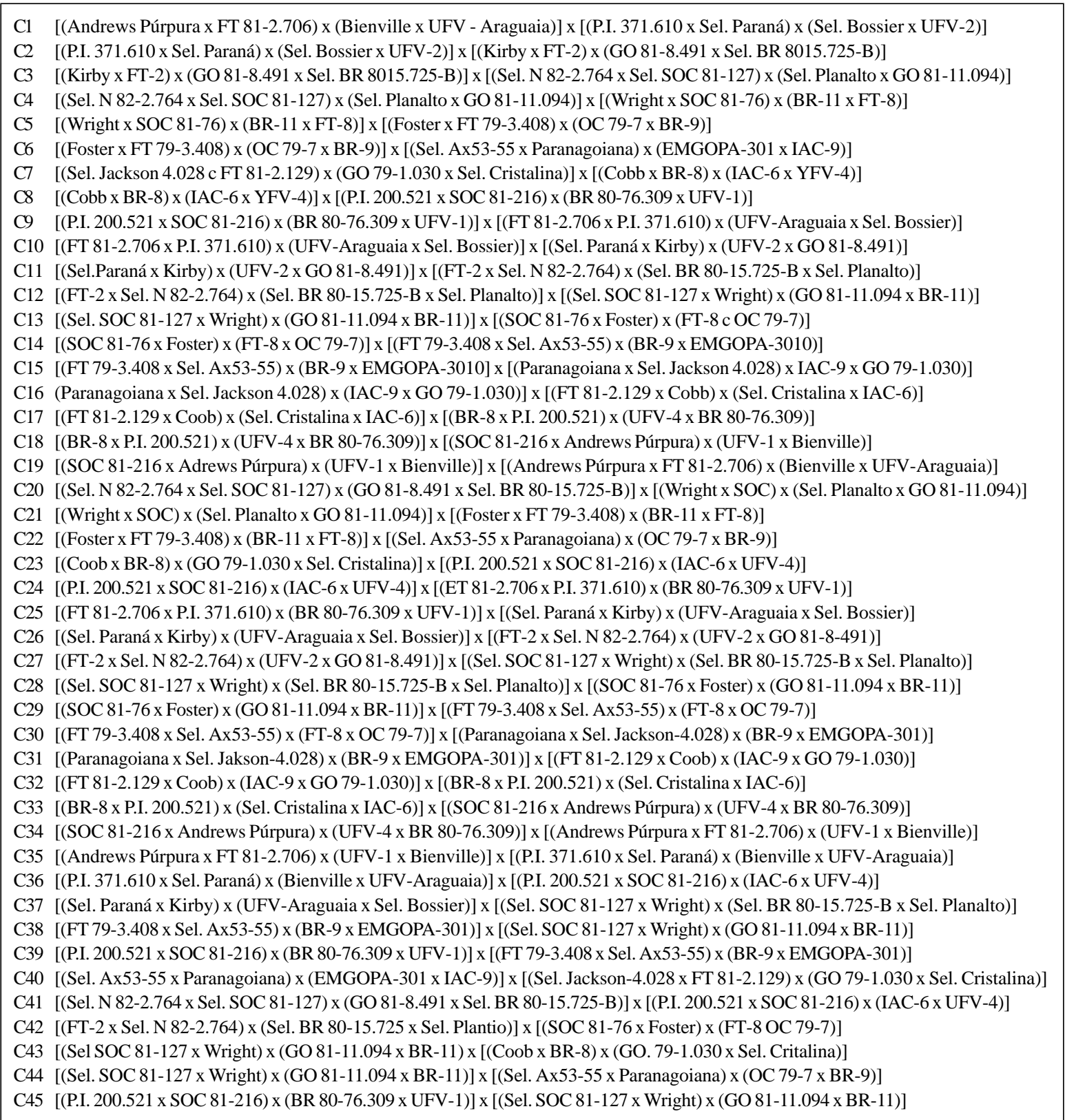

three crosses that had superior performance also in the progenies regrouped in early, intermediate and late subpopulations.

The estimates of Go for the OY characteristic are given in Tables IV and $\mathrm{V}$. The progenies selected in $\mathrm{F}_{4: 3[8]}$ showed considerable gains in $\mathrm{F}_{5: 3[8]}$. For $\mathrm{OY}$ the gains were within the range of 0 to $64.38 \%$ (C22), as in the crosses C14 with 57.05, C13 with 51.2 and C3 with $27.5 \%$. The crosses that had significant gains in the progenies $\mathrm{F}_{5: 3[8]}$ were C38 with 142.67, C2 with 86.5 and C23 with $79.37 \%$, all from the early subpopulation. In the intermediate subpopulation, C8 had a gain of 111.3, C6 had 99.68, and C12 had $88.71 \%$. Notable in the late subpopulation were those of C22 with a $125.4 \%$ gain, C14 with $85.78 \%$, and C20 with
$85.62 \%$. Particularly notable were the results of crosses $\mathrm{C} 2, \mathrm{C} 14$ and $\mathrm{C} 22$ with superior performances in the progenies $\mathrm{F}_{4: 3[8]}$ and $\mathrm{F}_{5: 3[8]}$, and significant magnitude of the estimates C38 and C8, with values greater than $100 \%$.

\section{ACKNOWLEDGMENTS}

The authors wish to thank CAPES, CNPq, EMBRAPA, FAPESP and FINEP for the scholarship and financial support to the projects that originated the germoplasm of the present study; the Soybean Laboratory workers - Antônio Roberto Cogo, Claudinei Didoné and Marcos Custódio Nekatschalow for their valuable experimental efforts, and the post-graduate students for their productive close association and friendship. Publication supported by FAPESP. 


\section{RESUMO}

Este estudo teve o objetivo de avaliar 44 cruzamentos óctuplos de soja, em cadeia, nas gerações $\mathrm{F}_{4: 3[8]}$ e $\mathrm{F}_{5: 3[8]}$, visando a seleção de progênies superiores quanto à produtividade de óleo e outros caracteres de importância agronômica. Os cruzamentos óctuplos foram sintetizados cruzando-se parentais adaptados $\mathrm{x}$ exóticos em um sistema de cadeia durante três gerações, até a obtenção de cruzamentos óctuplos tendo $75 \%$ genes adaptados: $25 \%$ genes exóticos em um grupo, e hibridações de parentais adaptados $\mathrm{x}$ adaptados, em cadeia, originaram cruzamentos óctuplos tendo $100 \%$ de genes adaptados, em outro grupo. No ano agrícola 1994/95 foram avaliadas as progênies $\mathrm{F}_{4: 3[8]}$, sendo empregado o delineamento em blocos aumentados. As progênies $\mathrm{F}_{5: 3[8]}$ foram conduzidas, no ano agrícola 1995/96, em três experimentos delineados em blocos aumentados (sem repetições). As análises dos resultados revelaram que cruzamentos óctuplos originaram progênies superiores para todos os caracteres estudados, inclusive em produtividade de óleo, obtendo-se valores de $707 \mathrm{~kg} / \mathrm{ha}$, no cruzamento C22. As estimativas de herdabilidade ao nível de médias de parcelas, em têrmos médios, mínimos e máximos, foram, respectivamente: tempo de maturidade $(52,35 \%$; $3,71 \% ; 84,23 \%)$, valor agronômico $(26,69 \% ; 1,62 \% ; 61,28 \%) \mathrm{e}$ produtividade de grãos $(29,28 \% ; 1,52 \% ; 61,06 \%)$; os ganhos genéticos observados para produtividade de grãos nas progênies $\mathrm{F}_{5: 3[8]}$ precoces, intemediárias e tardias foram, em geral, superiores aos respectivos ganhos genéticos esperados; e os ganhos genéticos observados para produção de óleo foram mais expressivos nas progênies $\mathrm{F}_{5:[8]}$ precoces e tardias. A existência de variabilidade genética remanescente entre progênies selecionadas de alguns cruzamentos permite antever a possibilidade de se obterem ganhos adicionais em ciclos mais avançados de seleção para produtividade de grãos e de óleo.

\section{REFERENCES}

Alliprandini, L.F. (1996). Potencialidade de cruzamentos quádruplos de soja com ênfase na produtividade de grãos. Doctoral thesis, Escola Superior de Agricultura "Luiz de Queiroz"/USP, Piracicaba.

Azevedo Filho, J.A. (1997). Potencialidade de linhagens experimentais de soja em solos contrastantes na saturação de alumínio. Doctoral thesis, Escola Superior de Agricultura "Luiz de Queiroz"/USP, Piracicaba.

Embrapa (1997). Recomendações técnicas para a cultura da soja na região Central do Brasil, 1997/98. Embrapa-Soja, Londrina.

Embrapa (1998). Recomendações técnicas para a cultura da soja na região Central do Brasil, 1998/99. Embrapa-Soja, Londrina, Documentos, 106.

Farias Neto, J.T. de (1995). Potencialidade de progênies $F_{4: 3}$ e $F_{5: 4}$ derivadas de cruzamentos em cadeia para produtividade de óleo em soja. Doctoral thesis, Escola Superior de Agricultura "Luiz de Queiróz"/USP, Piracicaba.

Federer, W.T. (1956). Augmented (or hoonuiaku) designs. Hawaii. Plant.
Rec. 55: 191-208.

Gomes, R.L.F. (1995). Análise genética de progênies $\mathrm{F}_{6}$ e $\mathrm{F}_{7: 6}$ de soja obtidas de cruzamentos dialélicos. Doctoral thesis, Escola Superior de Agricultura "Luiz de Queiróz"/USP, Piracicaba.

Hill, L., Bender, K., Bode, G., Beachy, K. and Dueringer, J. (1996). Quality choices in international soybean markets. Agribusiness 12: 231-246.

Hymowitz, T. (1970). On the domestication of soybean. Econ. Bot. 24: 408421.

Ininda, J., Fher, W.R., Cianzio, S.R. and Schnebly, S.R. (1996). Genetic gain in soybean population with different percentages of plant introduction parentage. Crop Sci. 36: 1470-1472.

Karmakar, P.G. and Bhatnagar, P.S. (1996). Genetic improvement of soybean varieties released in India from 1969 to 1993. Euphytica 90: 95103.

Laínez-Mejia, J.R. (1996). Implicações da interação genótipo x ambientes na seleção de progênies de soja com ênfase nas produtividades de grãos e óleo. Doctoral thesis, Escola Superior de Agricultura "Luiz de Queiróz"/USP, Piracicaba.

Lopes, A.C.A. (1997). Potencialidade de cruzamentos óctuplos de soja com ênfase na produtividade de grãos. Master's thesis, Escola Superior de Agricultura "Luiz de Queiroz"/USP, Piracicaba.

Miranda, M.A.C. (1994). Seleção recorrente divergente para peso de sementes e porcentagem de óleo em soja com o uso de machoesterilidade genética. Doctoral thesis, Escola Superior de Agricultura "Luiz de Queiroz", Universidade de São Paulo, Piracicaba.

Miranda, M.A.C. de, Teixeira, J.P.F., Mascarenhas, H.A.A. and Rettori, C. (1989). Possibilidade de seleção recorrente para aumento do teor de óleo em soja com a utilização da macho-esterilidade genética e da espectroscopia nuclear magnética. Bragantia 48: 157-172.

Montaño-Velasco, J.C. (1994). Análise genética de progênies $F_{3}$ de soja derivadas de cruzamentos em cadeia com ênfase na produção de óleo. Doctoral thesis, Escola Superior de Agricultura "Luiz de Queiroz"/ USP, Piracicaba.

Pantalone, J.R., Burton, J.W. and Carter Jr, T.E. (1996). Soybean fibrous root heritability and genotypic correlations with agronomic and seed quality traits. Crop Sci. 36: 1120-1125.

Rose, J.L., Butler, D.G. and Ryley, M.J. (1992). Yield improvement in soybeans using recurrent selection. Aust. J. Agric. Res. 43: 135-144.

Santos, C.A., Reis, M.S., Sediyama, C.S., Cruz, C.D. and Sediyama, T. (1995). Parâmetros genéticos e seleção indireta em progênies $F_{6}$ de um cruzamento de soja [Glycine max (L.) Merrill]. Rev. Ceres 42: 115-166.

SAS Institute (1987). SAS/STAT Guide for Personal Computers. Version 6. SAS Institute, Cary, NY.

Smith, K.J. and Huyser, W. (1987). World distribution and significance of soybean. In: Soybean: Improvement, Production and Uses (Wilcox, J.R., ed.). 2nd edn. ASA (Agronomy, Ser. of Monograghs, 16), Madison, pp. $1-22$

Toledo, F.J. (1990). Ganho genético em soja via melhoramento. Pesqui. Agropecu. Bras. 29: 1365-1371.

Uphoff, M.D., Fehr, W.R. and Cianzio, S.R. (1997). Genetic gain for soybean seed yield by three recurrent selection methods. Crop Sci. 37: $1155-1158$.

Vello, N.A. (1992). Ampliação da base genética do germoplasma e melhoramento de soja na ESALQ/USP. In: Simpósio sobre Cultura e Produtividade da Soja (Câmara, G.M.S., Marcos Filho, J. and Oliveira, E.A.M., eds.). FEALQ, Piracicaba, pp. 60-81.

(Received January 27, 2000) 